\title{
Ionic Liquid-Supported Oligosaccharide Synthesis
}

\author{
イオン液体を利用した糖鎖合成
}

Key Words: ion-liquid support, efficient synthesis, precipitation

In recent years, ionic liquids (ILs) have received great attention as environmentally benign reaction media for organic reactions. This is due to some intriguing properties of these liquids, namely their high thermal and chemical stability, including non-flammability and lack of measurable vapor pressure. By modifying the structure of the cation or the anion, the solubilities of ILs can be tuned readily so that they can phase-separate from organic as well as aqueous media. This offers the potential for ILs to serve as not only solvents, but also viable soluble functional supports for organic synthesis. Recently, some reports of the use of IL support as an efficient synthetic strategy have been published. Oligosaccharide synthesis exploiting IL support was first studied by Chan et al. [He, X., and Chan, T. H. (2006) Synthesis, 1645-1651] and Wang et al. [Huang, J.-Y. et al. (2006) Tetrahedron Lett. 47, 3047-3050]. Since then, various IL-supported oligosaccharide syntheses have been reported [e.g. Pathak, A. K. et al. (2008) Org. Lett. 10, 145-148; Yerneni, C. K. et al. (2009) J. Org. Chem. 74, 6307-6310]. Here, we describe recent studies of the use of IL support in oligosaccharide synthesis.

The typical strategy of IL-supported oligosaccharide synthesis is as follows. (1) The substrate anchored onto an IL moiety is soluble in polar organic solvents and can undergo liquid-phase reaction. (2) After completion of the reaction and evaporation of the solvent, the excess reagents can be removed by using a less polar organic solvent in which the $\mathrm{IL}-$ anchored product is insoluble. Inorganic reagents or side products can be removed by precipitation or by being washed with aqueous solution. (3) This procedure is repeated to give the desired structures or oligomers. (4) The product can be detached and then separated from the IL moiety by organic solvent extraction. (5) Final chromatographic purification of the crude product is conducted.

Early IL-supported oligosaccharide syntheses by using this technique were limited to only a singular functional linkage (ester linkage in C-4 or C-6) on the donor or acceptor. Therefore, J.-R. Li et al. further extended the IL-supported synthesis of oligosaccharides by using another IL linkage to demonstrate the broad scope of this convenient method [Huang, J.-Y. et al. (2011) Carbohydr. Polym. 83, 297-302]. They managed to establish a library of oligosaccharides by using an imidazolium cation as a soluble functional support, with ester and ether linkages. All IL-supported intermediates can be clipped off and purified by using a simple phase-
近年、イオン液体は有機合成の分野において環境調和型の 反応媒体になりうる存在として大きな注目を集めている。こ れはイオン液体の熱的あるいは化学的な安定性 (難燃性や蒸 気圧の低さなども含む) に寄るところが非常に大きい。また、 イオン液体は分子中のカチオンやアニオンの構造を改良する ことにより、溶解度を自由自在に変化させることが可能であ り、その結果水や有機溶媒と分離層を形成することができる。 このようにイオン液体は非常に興味深い性質を持ち、その魅 力的な性質であるが故に、有機合成の反応溶媒としてだけで はなく、可溶性の有機合成用機能性担体 (イオン液体夕グ) と してのポテンシャルを併せ持っている言いことが可能である。 そのような背景から近年、効率的合成手法の一環として、「イ オン液体夕グ法」を用いる例が数多く報告されている。糖鎖 合成の分野では Chan ら [He, X., and Chan, T. H. (2006) Synthesis, 1645-1651] や Wang ら [Huang, J.-Y. et al. (2006) Tetrahedron Lett. 47, 3047-3050]により初めて報告され、その後、様々な報 告が成されている [Pathak, A. K. et al. (2008) Org. Lett. 10, 145148; Yerneni, C. K. et al. (2009) J. Org. Chem. 74, 6307-6310] 本稿 では最近のイオン液体タグ法を用いる効率的な糖鎖合成の例 について紹介したい。

イオン液体夕グ法は一般に以下の手順で行われる。(1)ま ず基質をイオン液体分子に結合させる。その際の導入反応な どは極性溶媒中の液相反応で行うことが可能である。(2) 反応 終了後、溶媒を濃縮し、精製のための洗浄を行う。過剩に用 いた試薬などは、イオン液体に対する溶解度の低い低極性溶 媒を用いて洗浄することにより除去することが可能である。 また、無機性の試薬や副生成物は水による洗浄により除去す ることが可能である。(3)この操作を目的物の骨格を構築する まで繰り返す。(4) イオン液体タグを切り出し、有機溶媒抽出 により分離する。(5) 最後に得られた粗生成物のクロマト精製 を行う。

この方法を用いた初期のころのイオン液体タグ法による 糖鎖合成では、イオン液体夕グの糖への導入位置や結合方法 が限定的であった。すなわち、イオン液体分子の導入位置は 糖供与体や糖受容体の 4 位あるいは 6 位水酸基に限定され、 また結合方法はエステル結合のみであった。そこでJ.R. Li ら はこのイオン液体夕グ法を用いる糖鎖合成の汎用性を広げる ために結合位置や結合方法を拡充させ、糖鎖ライブラリーの 作成を行った [Huang, J.-Y. et al. (2011) Carbohydr. Polym. 83, 297 -302]。すわなち、糖との結合にエステル結合だけでなくエー テル結合を加えることで従来法より糖の導入可能な位置を増 やし、さらにイミダゾリウムカチオンをコアに有するイオン 液体タグを使用することで、様々なオリゴ糖を 1 回のカラム 
separation technique. The pure oligosaccharides can be achieved efficiently with minimal column chromatographic purification via this approach under homogeneous reaction conditions. Additionally, the IL-supported substrates are easily characterized by using conventional spectroscopic techniques.

Z.-J. Li et al. [Ma, Q. et al. (2011) J. Org. Chem. 76, 5652-5660] reported an improved purification process for IL-supported oligosaccharide synthesis. In their research, they encountered an obstacle: even though a coupling was still highly efficient according to the spectroscopic analysis, the recovery yield of the IL-supported product was very low. They assumed that this low recovery rate was attributable to the lesser role played by the IL moiety when larger oligosaccharides were attached to it. The use of existing purification techniques such as precipitation or solid-liquid extraction resulted in mechanical loss and was likely to limit the application of the technique to the synthesis of larger molecules. To overcome this problem, they established an improved purification process for IL-supported oligosaccharides. This novel purification procedure consists of mixed-solvent dissolution, evaporation, precipitation, and centrifugation steps. (1)The reaction mixture is first dissolved in a mixed solvent of dichloromethane and isopropyl ether. (2)Subsequently, the solvent is partially removed by rotary evaporation in vacuo. Dichloromethane evaporates before the isopropyl ether, because its boiling point is lower. (3)With the evaporation of polar solvent dichloromethane, IL-supported oligosaccharides are gradually precipitated. (4)After the complete removal of dichloromethane, the white precipitates in the isopropyl ether are collected by centrifugation to yield the product. This "dissolution-evaporation-precipitation" purification procedure was equivalent to the procedure of precipitation in a nonpolar solvent, but the new type of evaporation and precipitation gave higher recovery rates than the traditional precipitation procedure. By using the improved purification process, they achieved efficient synthesis of a nanosaccharide on IL support without chromatographic purification.

These results indicate that effective application of the IL-supported strategy should enable more efficient synthesis of various complex bioactive oligosaccharides.

\section{Reported by Kohtaro Goto}

The Noguchi Institute 1-8-1, Kaga, Itabashi-Ku, Tokyo, Japan

E-mail: kgoto@noguchi.or.jp

FAX: 81-3-5944-3222
精製を用いるだけでそれぞれ合成している。その結果糖鎖ラ イブラリーを効率的に作成することに成功している。その際、 すべてのイオン液体タグの結合した中間体は反応終了後、前 述した簡単な方法により精製することができ、最終的な目的 物はそれぞれ最小回数のカラムクロマトグラフィー精製によ り容易に得らルことに成功している。さらにそれら中間体の 分析は、通常の有機合成で用いる分析方法をそのまま使用す ることが可能である。

また、Z.-J.Liらはこのイオン液体夕グ法の分離精製手 法を改良し、従来のイオン液体夕グ法では困難であったより 大きな糖鎖の合成に成功している $[\mathrm{Ma}, \mathrm{Q}$. et al. (2011) J. Org. Chem. 76, 5652-5660]。従来のイオン液体夕グ法を用いた糖鎖 合成の問題点として、分子サイズの大きな糖鎖の合成の際、 グリコシル化反応自体は高収率で進行しているにもかかわら ず、洗浄後の目的物の回収率が非常に悪い場合があるという 問題があった。彼らはその低回収率の原因を大きな糖分子が 結合したためのイオン液体性の低下によるものだと推定した。 つまり従来の固液抽出による洗浄方法では、大きな糖鎖が結 合している場合にはイオン液体性が低下するので目的物の一 部が洗浄の際に溶出してしまい、その結果回収率が低下する と考えた。すなわち、従来の洗浄法では合成可能な糖鎖の大 きさに限界があると言わざるを得ない。そこでその問題を解 決するために、筆者らは新しい精製法を開発した。この改良 法は混合溶媒による溶解、濃縮、沈殿、遠心分離という４工 程から成り立っている。その概念を以下に説明する。(1)まず 反応終了後、反応混合物をジクロロメタンとイソプロピルエー テルの混合溶媒に溶解させる。(2) 続いて沸点の差を利用して ジクロロメタンのみを濃縮する。(3) その結果イオン液体タグ の結合した化合物が徐々に沈殿してくる。(4) ジクロロメタン のみを完全に濃縮後、イソプロピルエーテル中に析出してい る白い沈殿物を遠心分離により回収する。

以上の新しい分離精製法を用いることで、従来の固液抽出 法を用いる場合よりも高い回収率を得ることができる。実際 に筆者らはこの改良イオン液体夕グ法を用いることで従来法 では困難であった 9 糖の合成を効率的に達成している。

今後、これらのイオン液体夕グを効果的に利用していけ ば、カラムクロマトグラフィーなどの精製工程を大幅に簡略 化できるために、複雑な構造を持つ糖鎖が簡単に合成できる ことが期待される。

後藤 浩太朗

公益財団法人野口研究所 糖鎖有機化学研究室 